Contents lists available at http://ejournal.uin-suska.ac.id

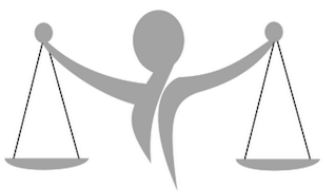

Al-Ittizaan: Jurnal Bimbingan Konseling Islam

ISSN: 2723-021X

Journal homepage: http://ejournal.uin-suska.ac.id/index.php/alittizaan

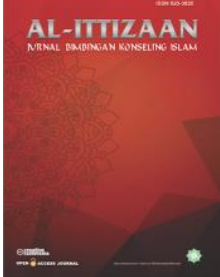

\title{
Kecemasan Mahasiswa Fresh Graduate Dalam Melamar Pekerjaan
}

\author{
Anisa Siti Nurjanah \\ Universitas Islam Negeri Sultan Syarif Kasim Riau
}

\begin{tabular}{|c|c|}
\hline Article Info & ABSTRACT \\
\hline Article history: & $\begin{array}{l}\text { The purpose of this research is to describe the level of anxiety of fresh } \\
\text { graduate students applying for jobs. The research focuses on the }\end{array}$ \\
\hline Received Feb $6^{\text {th }}, 2020$ & phonemenon of many fresh graduate students who are unemployed because \\
\hline Revised Feb $19^{\text {th }}, 2020$ & they feel anxious in applying jobs. Research using library research methods. \\
\hline Accepted Feb $21^{\text {th }}, 2020$ & $\begin{array}{l}\text { The data that researchers use in the form of books and journals related to } \\
\text { the research topic. The data obtained were analyzed using content analysis }\end{array}$ \\
\hline Keyword: & $\begin{array}{l}\text { techniqus. The results showed that students tend to be more anxious when } \\
\text { applying for jobs, especially at the interview stage than if they would be }\end{array}$ \\
\hline $\begin{array}{l}\text { Anxiety, } \\
\text { Fresh Graduate, } \\
\text { Unemployedment }\end{array}$ & $\begin{array}{l}\text { unemployed. Factors that make fresh graduate students feel anxious are the } \\
\text { lack of soft skills, lack of information about job and lack of confidence in } \\
\text { one's own abilities. }\end{array}$ \\
\hline
\end{tabular}

(C) 2018 The Authors. Published by UIN Sultan Syarif Kasim Riau.

This is an open access article under the CC BY license

(https://creativecommons.org/licenses/by/4.0)

\section{Corresponding Author:}

Anisa Siti Nurjanah

Universitas Islam Negeri Sultan Syarif Kasim Riau

Email: anisachacha4@gmail.com

\section{Introduction}

Mahasiswa adalah golongan intelektual yang mempunyai dua karakteristik yang menonjol, yaitu seorang pemuda dan calon intelektual (Prihastuti \& Rahmawati, 2012). Setiap mahasiswa pasti memiliki gambaran berbeda-beda mengenai dunia kerja dan memiliki keinginan yang berbeda pula untuk bekerja di instansi mana atau bekerja sebagai apa untuk sukses di masa depan dan tidak menjadi seorang pengangguran. Mahasiswa sebagai generasi milenial harus mampu menggunakan teknologi sebagai ruang keilmuan serta mempersiapkan diri menjadi seorang yang memiliki kemampuan yang baik sebagai persiapan menuju dunia kerja. Teknologi yang canggih harusnya mempermudah mahasiswa untuk mempersiapkan karirnya dengan cara mencari informasi mengenai pekerjaan yang diinginkan, mengikuti pelatihan soft skill untuk menunjang kemampuan sebelum memasuki dunia pekerjaan. Pemuda harus berperan penting serta mampu menyumbangkan karya-karya terbaiknya dalam pekerjaan. Hal ini diperkuat dengan peran pemuda sebagai agent of change yang melekat pada diri pemuda sebagai bagian generasi penerus bangsa yang harus siap memasuki dunia pekerjaan setelah lulus kuliah.

Berdasarkan data dari Badan Pusat Statistik (BPS) Kementerian Perencanaan Pembangunan Nasional (Bappenas) tentang statistik menyatakan jumlah penduduk Indonesia pada 2020 diperkirakan mencapai 134,92 juta jiwa perempuan dan 136,14 juta jiwa laki-laki. Sedangkan berdasarkan komposisitahun, 26,3\% pendudukan berusia 0-14 tahun, 67,7 \% penduduk berusia 15-64 tahun dan 6,2\% berusia di atas 65 tahun (TIM BPS, 2018). Usia 15-64 tahun merupakan penduduk usia produktif yang di dalamnya termasuk mahasiswa yang sedang mencari kerja. Salah satu hal yang harus dilakukan generasi intelektual yaitu mahasiswa adalah mampu memperoleh pekerjaan bahkan membuka lapangan pekerjaan untuk mengurangi pengangguran. Di sinilah letak keunggulan yang harus ditonjolkan. 
Sebelum individu mengambil suatu keputusan mengenai karirnya maka individu harus memiliki perencanaan karir terlebih dahulu. Individu disebut memiliki perencanaan karir apabila individu tersebut sudah memiliki pengetahuan dan pemahaman tentang dirinya dan pekerjaan yang ia inginkan. Sesuai dengan pernyataan yang mengatakan bahwa aspek terpenting dalam kehidupan manusia adalah ketika manusia tersebut dapat memperoleh pekerjaan sesuai dengan yang diinginkan (Mastur, 2014).

Namun, pada kenyataannya mahasiswa lulusan atau fresh graduate yang masih menganggur tidak merasa cemas jika ia dalam keadaan menganggur, tetapi rasa cemas mahasiswa fresh graduate akan muncul ketika mereka mulai melamar pekerjaan. Hal yang mencari penyebab munculnya kecemasan pada mahasiswa fresh graduate adalah tingginya angka pengangguran pada alumni suatu universitas dapat menimbulkan kegelisahan pada mahasiswa fresh graduate tentang kemungkinan mereka mendapat pekerjaan seperti alumni dan ketika mereka harus menghadapi tes wawancara.

Kecemasan muncul disebabkan oleh kepercayaan yang tidak irasional sehingga mempengaruhi pola pikir, emosi dan perilaku mahasiswa (Nur Isnaini, 2015). Faktor-faktor lain yang mempengaruhi kecemasan (Prihastuti \& Rahmawati, 2012), pertama fisik, kedua trauma dan konflk, ketiga kondisi, keempat hereditas dan lingkungan awal yang tidak baik. Hal ini juga sesuai pernyataan yaitu kecemasan yang dialami sarjana fresh graduate dalam proses melamar pekerjaan dapat berupa perasaan memiliki beban yang berat, muncul rasa takut, gelisah sehingga menggangu ketenangan bahkan kesehatan fisik individu (Prihastuti \& Rahmawati, 2012). Kualifikasi kerja yang menuntut peamar harus memiliki pengalaman kerja juga menjadi penyebab munculnya kegelisahan sedangkan fresh graduate merupakan lulusan baru lulus yang belum pernah bekerja sebelumnya (Rachmady \& Aprilia, 2018).

Salah satu faktor munculnya kecemasan saat wawancara adalah kurangnya soft skil mahasiswa lulusan baik itu public speaking, kemampuan bekerja sama, kurangnya pengalaman organisasi dan takut memulai sesuatu. Jika dihadapkan dengan kondisi yang sama, maka pikiran yang meyakini bahwa kegagalan akan terulang kembali membuat mahasiswa menjadi cemas ketika akan menghadapi wawancara. Perasaan cemas saat proses wawancara ditunjukkan dengan merasa tidak memiliki kemampuan, merasa orang lain lebih baik dari dirinya, merasa bahwa kegagalan selau mengikuti, khawatir tidak akan lulus dan tidak bekerja (Hadi \& Zubaidah, 2015). Perasaan cemas yang tidak diatas pada mahasiswa fresh graduate akan menimbulkan perilaku negatif yaitu individu menghindari mendapatkan kondisi yang sama. Perilaku menghindari masalah dalam persaingan pekerjaan dapat menghambat individu dalam mendapat pekerjaan (Mu'arif, 2005).

Tujuan penelitian ini adalah untuk memberikan gambaran tentang kecemasan yang dialami mahasiswa fresh graduate dalam mencari pekerjaan. Untuk mengatasi rasa cemas pada mahasiswa maka seharusnya mahasiswa meningkatkan kesiapan kerja sebelum melamar pekerjaan. Fresh graduate diharapkan mampu mengatasi rasa cemasnya, sehingga mereka dapat fokus dalam mendapatkan pekerjaan daripada harus memikirkan kesulitan dalam mendapatkan pekerjaan tersebut.

\section{Method}

Penelitian menggunakan pendekatan kualitatif dengan menerapkan metode library research. Penelitian ini menggunakan literatur sebagai obyek kajian. Data yang digunakan dalam penelitian ini berupa data sekunder, yaitu buku-buku, majalah-majalah dan dokumen-dokumen tertulis. Selain itu digunakan juga artikelartikel dari yang diambil dari jurnal-jurnal yang berkaitan (Tjiptohadi Sawarjuwono, 2003). Teknik analisis yang digunakan adalah teknik content analysis dengan menggunakan data hasil penelitian sebagai sumber dalam menjawab pertanyaan penelitian.

\section{Results and Discussions}

Dari berbagai literatur yang telah dibaca, maka dapat dipahami bahwa mahasiswa fresh graduate lebih merasa cemas saat melamar pekerjaan terutama pada saat tahap wawancara dibanding pengangguran. Mahasiswa fresh graduate yang menganggur bukan disebabkan oleh tinggi rendahnya IPK (Indesk Prestasi Kumulatif) yang didapatkan selama perkuliahan melainkan rendahnya soft skill atau kemampuan di luar mata kuliah (Nur Isnaini, 2015). Lebih lanjut, mahasiswa fresh graduate cenderung tidak tahu apa yang harus dilakukan setelah lulus dari universitas. Kondisi tersebut menjadi penyebab timbulkan kecemasan pada lulusan baru (Calson dalam Nur Isnaini, 2015).

Hasil penelitian lain mengatakan jumlah sarjana pengangguran lebih banyak dibandingkan lulusan SMK/SMA yang menganggur. Artinya, lulusan SMK/SMA lebih banyak diserap oleh industri ketimbang lulusan sarjana. Lulusan SMK dipilih karena mereka cenderung memiliki kemampuan yang bagus di bidang yang dipelajari semasa sekolah, apalagi sekolah kejurusan banyak memfokuskan pada kerja praktek dibandung teori. Sementara, sarjana lebih banyak mempelajari teori dibanding praktek. Hal ini terjadi akibat, mayoritas sektor industri di Indonesia tidak butuh tenaga yang terlalu pintar tetapi tidak memiliki kemampuan khusus. 
Tenaga yang terlalu pintar dianggap banyak menuntut, terutama soal gaji, ini yang membuat industri berpikir berulang kali untuk merekrut sarjana (Alam, 2016). Lulusan SMK dipilih karena mereka cenderung memiliki kemampuan yang bagus di bidang yang dipelajari semasa sekolah, apalagi sekolah kejurusan banyak memfokuskan pada kerja praktek dibandung teori. Sementara, sarjana lebih banyak mempelajari teori dibanding praktek. Maka, untuk mengurasi kecemasan dalam tahap wawancara pekerjaan, mahasiswa fresh graduate harus memiliki kompetensi khusus yang menunjang karirnya di masa depan. Kemampuan tersebut bisa didapatkan dari berbagai kegiatan pelatihan yang informasinya tersebar di media-media.

Selain itu, pembekalan berupa teori yang diberikan selama proses perkuliahan kurang memberikan pengaruh yang besar bagi mahasiswa untuk mendapatkan pekerjaan (Prasetyo, 2013). Hal ini membuat mahasiswa merasa cemas tidak akan lolos ketika pelamar pekerjaan. Persiapan untuk terjun ke dunia kerja belum dimiliki oleh masing-masing mahasiswa. Banyak mahasiswa yang justru kebingungan tentang apa bakat dan kemampuan yang ia miliki, padahal kemampuan itulah yang akan menjadi bahan jawaban dalam proses wawancara. Hal ini sejalan dengan pernyataan bahwa kompetensi mahasiswa di UGM dan UIN Sunan Kalijaga Yogyakarta mempengaruhi kesiapan mereka dalam menghadapi AEC 2015 (Setyaningsih, 2015). Jika mahasiswa memiliki kompetensi yang cukup untuk menunjang pekerjaannya maka mahasiswa akan merasa siap saat proses wawancara.

Faktor lain yang menyebabkan mahasiswa merasa cemas ketika meghadapi proses wawancara adalah rasa percaya diri yang kurang. Mahasiswa fresh graduate mengalami kecemasan karena takut tidak diterima pada perusahaan yang mereka lamar. Hasil penelitian menunjukan bahwa Kepercayaan diri memiliki hubungan yang erat dengan kesiapan kerja para siswa SMK (Yudi Ganing Utami, 2013). Hal ini juga sesuai dengan permasalahan kecemasan yang di alami mahasiswa pelamar pekerjaan. Di mana mereka harus memiliki kepercayaan diri untuk menjawab pertanyaan saat wawancara. Jika mahasiswa memiliki kompetensi yang cukup untuk menunjang pekerjaannya maka mahasiswa akan merasa siap saat proses wawancara. Mahasiswa fresh graduate diharapkan bisa mengatasi rasa cemas sehingga tidak mengganggu ketenangan dan bisa mengasah kemampuan. Adversity quotient atau lebih dikenal dengan kemampuan seseorang dalam mengatasi kesulitan hidup dan mengukur kemampuannya. Semakin tinggi adversity quotient maka semakin rendah kecemasan menghadapi dunia kerja karena adversity quotient yang dimiliki oleh fresh graduate akan memengaruhi kecemasan menghadapi dunia kerja pada fresh graduate tersebut (Rachmady \& Aprilia, 2018).

Faktor lain yang mempengaruhi kecemasan melamar pekerjaan adalah dari dukungan keluarga dan banyaknya saingan dalam mendaftar pekerjaan (Mustikasari, 2018). Keluarga berperan penting dalam proses karir individu. Dukungan serta semangat yang diberikan keluarga untuk individu yang sedang melamar pekerjaan memberikan dampak terhadap keyakinan individu tersebut. Meskipun ketika melamar pekerjaan di suatu instansi memiliki saingan yang cukup banyak namun, dukungan dari orang terdekat akan membangkitkan rasa juang individu dalam melamar pekerjaan.

\section{Conclusions}

Dari berbagai sumber yang telah dikemukakan di atas, dapat dipahami bahwa mahasiswa fresh graduate cenderung lebih cemas menghadapi proses melamar kerja dibanding menganggur. Hal ini disebabkan banyak faktor yaitu kurangnya soft skill yang dimiliki mahasiswa, kurangnya informasi mengenai pekerjaan dan kurangnya kepercayaan terhadap kemampuan diri sendiri. Soft skill yang harusnya dimiliki oleh lulusan universitas semasa kuliah, antara lain bidang komputer, Bahasa Inggris, pelatihan enterpreneurship, leadership dan ketenagakerjaan.

\section{References}

Alam, S. (2016). Tingkat Pendidikan Dan Pengangguran Di Indonesia (Telaah Serapan Tenaga Kerja Sma/Smk Dan Sarjana). Jurnal Imiah BONGAYA (Manajemen \& Akuntansi), (Xix), 250-257.

Hadi, M. F. Z., \& Zubaidah, Z. (2015). Pemanfaatan Konseling Neuro Linguistic Programming dalam Mengatasi Kesulitan Belajar Siswa Sekolah Dasar. Jurnal Dakwah Risalah, 26(4), 174-182.

Mastur, T. (2014). Materi Layanan Klasikal Bimbingan dan Konseling Bidang Bimbingan Karier. YOGYAKARTA: PARAMITAP PUBLISHING.

Mu'arif. (2005). Hubungan Kecemasan dengan Agresifitas. Humanitas Indonesia. Pscychological Journal, 2, $1012-11$.

Nur Isnaini, N. S. (2015). Kecemasan Pada Pengangguran Terdidik Lulusan Universitas. Jurnal Indigenous, 13(1), 39-50.

Prasetyo, J. (2013). Pengembangan kewirausahaan yang didukung penelitian di bidang kewirausahaan di perguruan 
tinggi sebagai cara alternatif mengurangi tingkat pengangguran terdidik. 5(2), 92-98.

Prihastuti, N. W. S., \& Rahmawati. (2012). Tingkat kecemasan sarjana. 4(3), 2-6.

Rachmady, T. M. N., \& Aprilia, E. D. (2018). Hubungan Adversity Quotient Dengan Kecemasan Menghadapi Dunia Kerja Pada Freshgraduate Universitas Syiah Kuala Correlation Adversity Quotientand the Anxiety in Facing the Working World on Fresh graduate from Syiah Kuala University. 6(1), 54-60.

Setyaningsih, I. (2015). Kompetensi untuk Menakar Kesiapan Mahasiswa Menghadapi Persaingan Asean Economic Community. JurnalSeminar NasionalIenaco, 1, 440-446.

TIM BPS. (2018). DATA PENDUDUK INDONESIA.

Tjiptohadi Sawarjuwono, A. P. K. (2003). Intelectual Capital: Perlakuan, Pengukuran dan Pelaporan (Sebuah Library Research). Jurnal Ilmiah Bongaya, 5, 43.

Yudi Ganing Utami, D. H. (2013). Self Efficacy dengan Kesiapan Kerja Siswa Sekolah Menengah Kejuruan. Jurnal Ilmiah Psikologi Terapan, 1. 